

\section{Commune-level institutional arrangements and monitoring framework for integrated tree-based landscape management}

Vu Tan Phuong, Nguyen Van Truong, Do Trong Hoan

ICRAF working paper no. 318 


\section{줄 \\ World \\ Agroforestry}

\section{Correct citation}

Vu TP, Nguyen VT, Do TH. 2021. Commune-level institutional arrangements and monitoring framework for integrated treebased landscape management. Working Paper No.318. Ha Noi, Viet Nam: World Agroforestry (ICRAF).

DOI: https://dx.doi.org/10.5716/WP21024.PDF

Titles in the Working Paper Series aim to disseminate interim results on agroforestry research and practices and stimulate feedback from the scientific community. Other publication series from the World Agroforestry include: Agroforestry Perspectives, Technical Manuals and Occasional Papers.

Published by World Agroforestry (ICRAF)

Jalan CIFOR, Situ Gede, Sindang Barang

Bogor Barat 16115, Jawa Barat

Indonesia

Tel: +62 2518625415

Fax: +62 2518625416

Email: icraf-indonesia@cgiar.org

Internet: http://www.worldagroforestrycentre.org/sea

(c) World Agroforestry (ICRAF) 2021

\section{Disclaimer and copyright}

The views expressed in this publication are those of the author(s) and not necessarily those of World Agroforestry (ICRAF). Articles appearing in this publication may be quoted or reproduced without charge, provided the source is acknowledged. All images remain the sole property of their source and may not be used for any purpose without written permission of the source.

The geographic designations employed and the presentation of material in this publication do not imply the expression of any opinion whatsoever on the part of World Agroforestry (ICRAF) concerning the legal status of any country, territory, city or area or its authorities, or concerning the delimitation of its frontiers or boundaries. 


\section{ABOUT THE AUTHORS}

Vu Tan Phuong $(\mathrm{PhD})$ is the director of the Training and International Cooperation Department of the Vietnamese Academy of Forest Sciences. He has a forestry background with over 20 years working experience in Viet Nam, particularly in the field of forestry, environment and forest governance. He is one of the leading experts in developing national policies on Payment for Forest Environmental Services and Reducing Emission from Deforestation and forest Degradation (REDD+).

Nguyen Van Truong (MSc) is a researcher with the Viet Nam Academy of Forest Sciences. He obtained his Master of Science degree from Hanoi University of Science. As a forester, Truong focuses on the measurement and quantification of tree biomass and carbon-storage potential of forest ecosystems in Viet Nam. His research interests also extend into payments for ecosystem services, especially, the implementation of policies on the ground and the issues of fair and efficient benefit sharing.

Do Trong Hoan (MSc) is a researcher with World Agroforestry (ICRAF) in Viet Nam. He obtained his Master of Science degree from Pohang University of Science and Technology, South Korea. He has been involved in research in climate-change mitigation and forest ecosystem services since 2004. His research interests are concentrated in the area of natural resource management, including incentive-based forest conservation, climate-change mitigation through REDD+ and carbon-trade schemes, forest-land tenure, benefit-sharing mechanisms for smallholders, and economic analyses of forest and agroforestry land-use systems. 


\section{Acknowledgements and disclaimer}

This work was undertaken as part of the CGIAR Research Program on Policies, Institutions and Markets (PIM) led by the International Food Policy Research Institute (IFPRI). The study was conducted by ICRAF and Viet Nam Academy of Forest Science scientists and researchers working in collaboration in the Developing and Promoting Market-based Agroforestry and Forest Rehabilitation Options for Northwest Vietnam (2017-2021) project. Funding was provided by the Australian Centre for International Agricultural Research (ACIAR) and the CGIAR Research Program on Forests, Trees and Agroforestry (FTA).

The opinions expressed herein belong to the authors and do not necessarily reflect those of ACIAR, ICRAF, PIM, FTA, IFPRI or CGIAR.
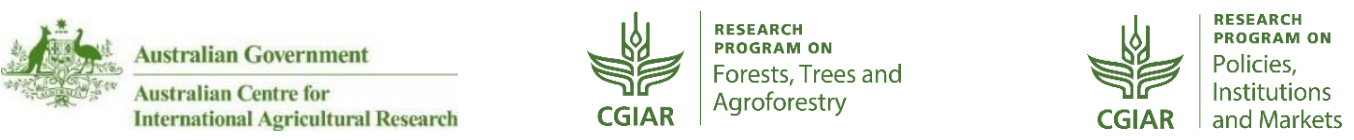


\section{Contents}

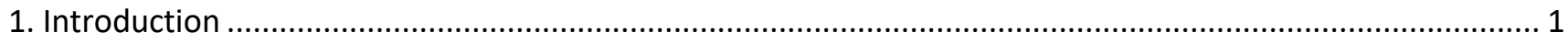

2. Legal framework for land-use planning and green-growth development............................................... 2

3. Institutional arrangements for land and forest management ............................................................ 5

4. Limitations and challenges in planning for land use and green-growth development ............................... 7

5. Proposed institutional arrangements and monitoring frameworkfor integrated tree-based landscape

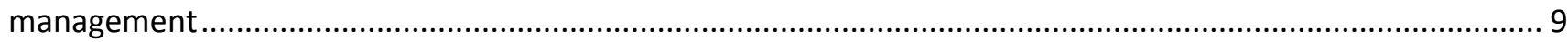

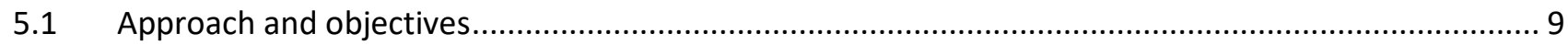

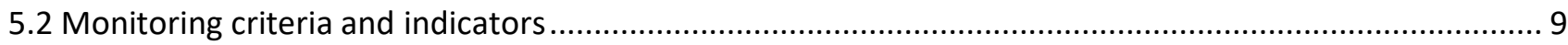

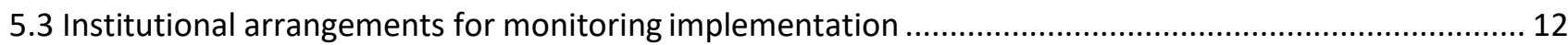

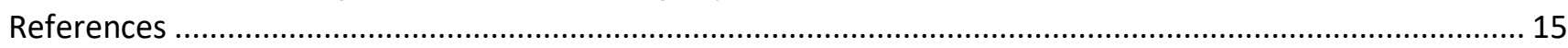

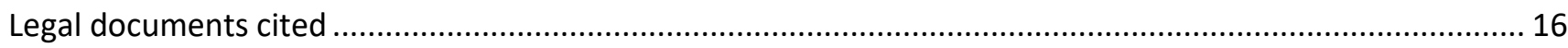

Annex 1. Additional guidelines on development of indicators for monitoring integrated tree-based landscape

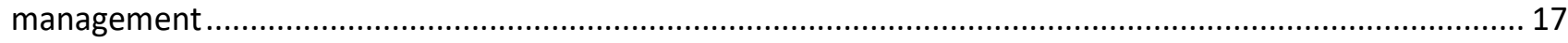

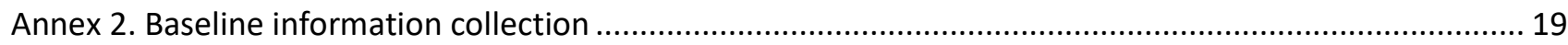

Annex 3. Monitoring framework for integrated tree-based landscape management ................................. 21

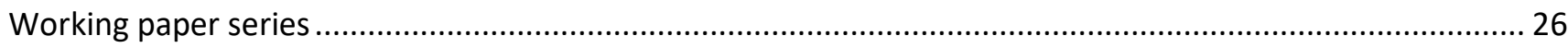




\section{Introduction}

Governance is a difficult task in the context of achieving landscape multifunctionality owing to the multiplicity of stakeholders, institutions, scale and ecosystem services: the 'many-multiple' (Cockburn et al 2018). Governing and managing the physical landscape and the actors in the landscape requires intensive knowledge and good planning systems. Land-use planning is a powerful instrument in landscape governance because it directly guides how actors will intervene in the physical landscape (land use) to gain commonly desired value. It is essential for sustaining rural landscapes and improving the livelihoods of rural communities (Bourgoin and Castella 2011, Bourgoin et al 2012, Rydin 1998), ensuring landscape multifunctionality (Nelson et al 2009, Reyers et al 2012) and enhancing efficiency in carbon sequestration, in particular (Bourgoin et al 2013, Cathcart et al 2007). It is also considered critical to the successful implementation of land-based climate mitigation, such as under Nationally Determined Contributions (NDCs), because the Land Use, Land-Use Change and Forestry (LULUCF) sector is included in the mitigation contributions of nearly 90 percent of countries in Sub-Saharan and Southern Asia countries and in the Latin American and Caribbean regions (FAO 2016).

Viet Nam has been implementing its NDC, which includes forestry and land-based mitigation options under the LULUCF sector. The contribution of the sector to committed national emission reduction is significant and cost-effective compared with other sectors. In addition to achieving emission reduction targets, implementation of forestry and land-based mitigation options has the highest benefits for social-economic development and achieving the Sustainable Development Goals (MONRE 2020). Challenges, however, lie in the way national priorities and targets are translated into sub-national delivery plans and the way sub-national actors are brought together in orchestration (Hsu et al 2019) in a context where the legal framework for climate-change mitigation is elaborated at national rather than sub-national levels and coordination between government bodies and among stakeholders is generally ineffective (UNDP 2018).

In many developing countries, conventional 'top-down', centralized land-use planning approaches have been widely practised, with very little success, a result of a lack of flexibility in adapting local peculiarities (Amler et al 1999, Ducourtieux et al 2005, Kauzeni et al 1993). In forest-agriculture mosaic landscapes, the fundamental question is how land-use planning can best conserve forest and agricultural land, both as sources of economic income and environmental services (O'Farrell and Anderson 2010).

This paper provides guidance on monitoring integrated tree-based landscape management at commune level, based on the current legal framework related to natural resource management (land and forest) and the requirements of national green-growth development and assessment of land uses in two communes in Dien Bien and Son La provinces. The concept of integrated treebased landscape management in Viet Nam is still new and should be further developed for wider application across levels. 


\section{Legal framework for land-use planning and green-growth development}

Viet Nam has issued numerous polices governing land-use planning, natural resource management, climate-change mitigation and adaptation, ecosystem services and green growth to achieve socio-economic development through sustainable management of its natural resources. The key policies are summarized below.

Land Law $2013^{1}$ requires land-use planning and preparation of land-use plans from central to local levels (Article 35). Land-use planning is conducted for a period of 10 years and land-use plans are prepared for 5-year periods. The law also regulates that land-use planning and plans have to be implemented at three levels: national, provincial and district (articles 37 and 38). The basis for the development of land-use plans across levels is mainly information on socio-economic development and sectoral plans, land-use status and land potential. Land-use planning for lower levels must ensure compliance with higher levels.

Planning Law $\mathbf{2 0 1 7}^{2}$ provides the general requirements for overall planning at different levels (national, regional and provincial) and sectors, including socio-economic activities, national defence and security associated with the development of infrastructure, resource use and environmental protection in determined territories to effectively use the country's resources for the purpose of sustainable development for a planned time period. This law requires taking into consideration various factors during the planning process, as outlined below.

- National infrastructure planning (Section 3, Article 25): Orientation of land-use arrangements for development of the national infrastructure sector and environmental protection and climate-change response activities and conserving national-ranked ecology, landscapes and monuments.

- National resource planning (Section 4, Article 25): Orientation for environmental protection, natural disaster prevention, and response to climate change (Point g, Section 4, Article 25).

- National environmental protection planning (Section 5, Article 25): Assessment of the status of, and changes in, environmental quality, natural landscapes and biodiversity; the situation and forecast of waste generation; impact of climate change; the situation of environmental management and protection; environmental zoning, nature and biodiversity conservation; waste management; environmental monitoring and warnings.

- Planning for biodiversity conservation (Section 6, Article 25): Identifying and zoning high-value biodiversity areas, important ecological and landscapes areas, nature reserves, biodiversity corridors and biodiversity conservation facilities.

Forestry Law $2017^{3}$ regulates the use and management of forests according to designated functions, including production forests (mainly for timber production), protection forests (watershed and coastal protection) and special-use forests (gene and biodiversity conservation).

\footnotetext{
${ }^{1}$ Land Law No. 45/2013/QH13 dated 29 November 2013

2 Land Law No. 45/2013/QH13 dated 29 November 2013

${ }^{3}$ Forestry Law No. 16/2017/QH14 dated 15 November 2017
} 
The law importantly recognizes the significance of environmental services provided by forests. These services are regulated in Article 6: 1) Protection of soil and minimization of erosion and sedimentation in lakes, rivers and streams; 2 ) Regulation and maintenance of water sources for production and everyday life; 3) Absorption and retention of forest carbon; reduction of greenhouse-gas emissions by reducing forest loss and deterioration, sustainable forest management, and green growth; 4) Protection and maintenance of natural beauty and landscapes, and preservation of the biodiversity of forest ecosystems for tourism services; and 5) Provision of breeding grounds, food sources, natural breeders, forest-based water sources and elements from forest environment and ecosystems for aquaculture cultivation.

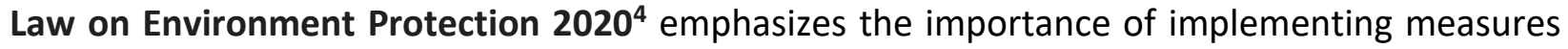
in response to climate change, particularly, ecosystem-based adaptation measures (Article 90, Chapter V). It also requires implementing mitigation measure for greenhouse-gas reduction and measurement and monitoring of emissions (Article 91, Chapter V).

National Strategy on Climate Change ${ }^{5}$ provides the legal framework to respond to climate change. The relevant actions related to land uses are reforestation and sustainable forest management to help mitigate natural disasters and land degradation, to strengthen the protection and development of coastal mangrove forests and wetland ecosystems, to reduce forest-related carbon emission, and to enhance carbon sequestration. Specific targets related to LULUCF are 1) Increase forest cover to 45\%; 2) Sustainable management of 16.24 million ha of forest land, of which 8.1 million ha is production forests; 5.8 million ha is protection forests and 2.1 million ha is special-use forest; and 3) Develop and implement programs and projects on emission reduction, carbon enhancement and sustainable forest management.

National Strategy on Green Growth ${ }^{6}$ provides green-growth targets in three broad categories: 1) low-carbon economic development; 2) enrichment of natural resources; and 3) emission reduction and carbon enhancement. In the forestry and land-use sector, it encourages actions on forest restoration, avoided emissions associated with land-use change, low-carbon development, biodiversity conservation and enhancement of carbon sequestration. To assess green growth, a draft set of criteria was proposed, focusing on three key aspects: 1) reduction of national emission intensity at a rate of $1.5-2.0 \%$ per year but, in the energy sector, the emission reduction targets aim at 20-30\% compared to business as usual; 2) greening production, which focuses on reviewing and updating existing planning; using resources economically and efficiently; encouraging the development of green industry and agriculture with appropriate structures of industries, technologies and equipment to ensure environmentally friendly principles are followed, and investment in development of natural capital and pollution prevention; and 3) Greening lifestyles and promoting sustainable consumption that emphasizes waste management, environmental improvement and urban tree areas.

The Ministry of Investment and Planning is now preparing national criteria for green-growth monitoring and evaluation. It focusses on three aspects: 1) greenhouse-gas emission reduction

\footnotetext{
${ }^{4}$ Environment Protection Law No. 72/2020/QH14 dated 17 November 2020

5 Prime Minister Decision No. 2139/QD-TTg dated on 5 December 2011

${ }^{6}$ Prime Minister Decision 1393/QD-TTg dated 25 September 2012
} 
and promotion of clean and renewable energy; 2) Greening production; and 3) Greening lifestyles and promotion of sustainable consumption. The following are the key tasks for the agriculture sector to monitor green growth.

- Reducing greenhouse-gas emissions through the development of sustainable organic agriculture and enhancing the competitiveness of agricultural production. The indicators include 1) The amount of chemical fertilizers and pesticides used per hectare of arable agricultural land; 2) Existing forest area; 3) Forest cover; 4) The ratio of biomass fuel extracted from agriculture, forestry and fisheries to the total fuel used.

- Economical and efficient use of resources. The expected indicators include 1) Area and land-use structure; 2) Proportion of fisheries reserves at the limit of ecological sustainability; 3) Ratio of the area of degraded land to total land area; 4) Proportion of natural ecosystems of international importance, degraded country restored; biodiversity preserved and used sustainably.

- Sustainable infrastructure development: Traffic, energy, irrigation and urban infrastructure, including the following indicator 1) Ratio of crop land to be irrigated and drained with controlled irrigation.

- Technological innovation, popularization of cleaner production, including 1) Percentage of cultivated land applying good agricultural practices (GAP and equivalents: climatesmart agriculture, ecosystem-based adaptation etc; 2) Proportion of aquacultural area reaching GAP and equivalents; 3) The proportion of enterprises eligible to obtain ISO 14001 certification compared to total number of businesses operating; 4) Proportion of craft villages meeting environmental requirements.

Forestry Development Strategy 2021-2030 and Vision to 2050 prioritizes management of forest resources for improved ecosystem services, biodiversity, natural disaster reduction and responses to climate change. It also aims to set up a national forest estate and prepare forestry plans for 2021-2030.

In summary, the current legal documents recognize the significance of, and need for, integration of environmental-related issues in planning processes to maintain and improve forest resources and ecosystem services to achieve green-growth objectives and to respond effectively to climate change.

However, the monitoring of this integration lacks detailed legal guidance, especially, for the forestry and land-use sector and at local management level.

\footnotetext{
${ }^{7}$ Prime Minister Decision 523/QD-TTg dated 1 April 2021
} 


\section{Institutional arrangements for land and forest management}

The Land Law 2013 and Forestry Law 2017 are the key pieces of legislation governing forests and land management across levels (central, provincial, district and commune). A unified management of land and forests is operated from central to local level by responsible State agencies. The figure below provides overall requirements and responsibilities for preparation and approval of land use planning across levels.

Figure 1. Land-use planning and preparation of plans across levels

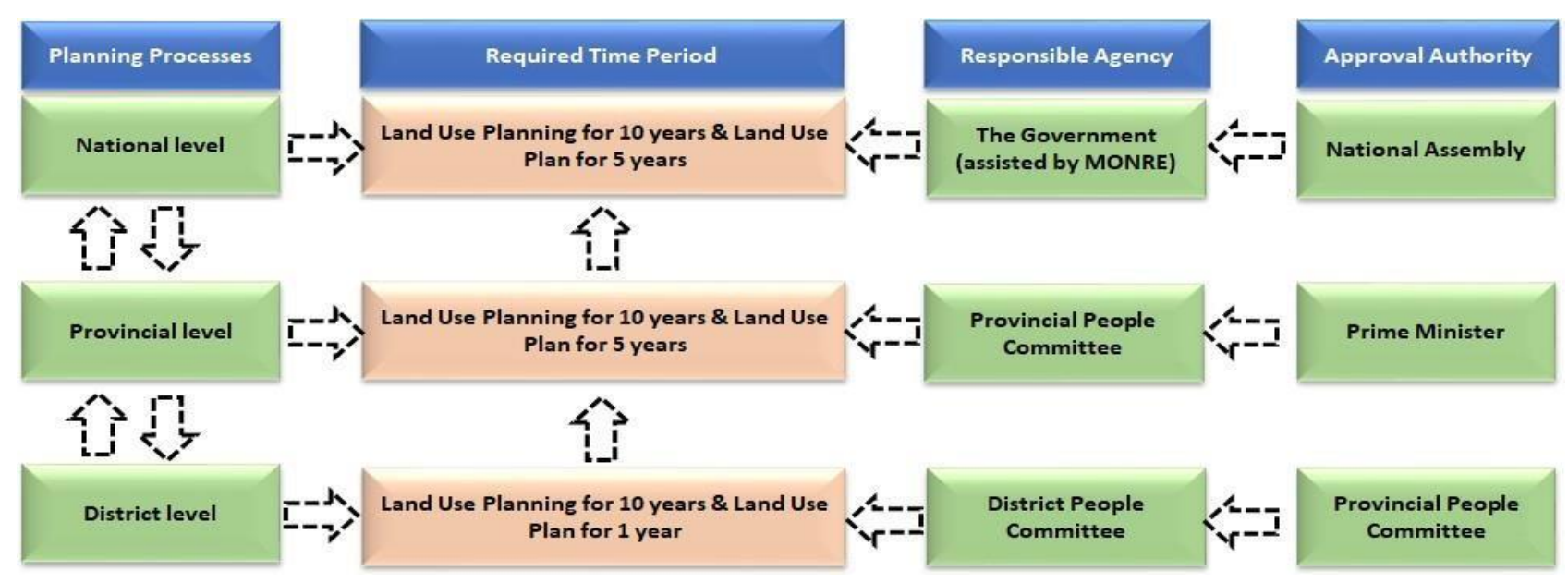

The roles and responsibilities of State management agencies engaged in land and forest resource management are summarized below.

- National Assembly: 1) Approval of laws, national land-use planning (10-year period), national land-use plan (5-year period) and other national planning; 2) Approval of plan on changing function of special-use forests, watershed protection forests and frontier protection forests with change of 50 ha or more; coastal protection forests with change of 500 ha or more; and production forests with change over 1000 ha.

- Government of Viet Nam: Approval of legal documents (decrees) on land and forest management, provincial land-use planning (10-year period) and land-use plans (5year period) and other planning (national defence and security etc).

- Prime Minister: 1) Approval of sectoral planning and development strategies, national target programs etc; 2) Approval of plan on changing function of special-use forests, watershed protection forests and frontier protection forests with change of 20-50 ha; coastal protection forests with change of 20-500 ha; and production forest with change of 50-1000 ha.

- Ministry of Natural Resources and Environment (MONRE): 1) Prepare legal documents (for example, laws, decrees, sectoral plans, strategies) for managing land and biodiversity resources to submit for approval; 2) Prepare national land-use 
planning and land-use plan to submit to National Assembly for approval; 3) Appraisal of provincial land-use planning and land-use plan; 4) Implement national land-use inventory every 5 years; 5) Prepare sectoral planning (biodiversity, environmental protection etc); 6) Report annually the implementation of approved land-use planning and land-use plans to Government of Viet Nam. Under MONRE, there is the Department of Natural Resources and Environment (DONRE) at provincial levels and the Division of Natural Resources and Environment (DiNRE) at district levels to support MONRE and provincial people's committees implement State management of land and environment.

- Ministry of Agriculture and Rural Development (MARD): 1) Prepare legal documents (for example, laws, decrees, sectoral plans, strategies) for managing forest resources to submit for approval; 2) Implement national forest inventory every 5 years; 3) Prepare national programs on forest management and development for approval. Management of forest resources at local level is supported by the Department of Forest Protection at provincial level and Forest Protection Stations at district level.

- Provincial People's Committee: 1) Prepare provincial land-use planning and land-use plan; 2) Approval of district land-use planning and land-use plan; 3) Report implementation of approved land-use planning and plan to MONRE; 4) Allocate and lease land and forests; decide changes in land and forest use; revoke allocated land and forests for land users and forest owners as organizations; 5) Submit to the Provincial People's Council for approval of plans on changing function of special-use forests, watershed protection forests, frontier protection forests and coastal protection forests with change of less than 20 ha; and production forest with change of less than 50 ha.

- District People's Committee: 1) Prepare and submit land-use planning and annual land use plan to PPC for approval; (2) Allocate and lease land and forests; make decision on conversion of land and forest use purposes; revocation of land and forests for land users and forest owners who are individuals, households and community;

- Commune People Committee (CPC): (1) Report implementation of approved land use planning and land use plan to DPC; (2) Make decision on land lease for land used for public purpose of the commune; (3) Manage forests that are yet allocated to forest owners.

- Stakeholders engaged directly in land and forest management: individuals and organizations allocated and rented land and forests for management and business. These actors include:

Forest management boards of special-use forests; forest management boards of protection forests; economic entities, including enterprises, forest companies, cooperatives and other types of legally established economic entities; military units; organizations operating in the fields of science and technology, education and training, and vocational training in forestry; local households and individuals; communities; and foreign-invested enterprises renting land to invest in production forests. 


\section{Limitations and challenges in planning for land use and green- growth development}

The implementation of land-use planning and integration of green-growth development into planning processes reveals several limitations and challenges, as follow (Do et al 2019, Vu et al 2018).

Top-down planning and lack of local participation in decision-making processes. Policies and decisions relating to resource management in Viet Nam are often imposed from the top down and lower-level agencies must act within the scope limited by their direct superiors. Public consultations on land-use planning and land-use plans are required at district and provincial levels. At those levels, consultation meetings are often attended by representatives of line management departments and representatives of the concerned private sector. At the commune level, village heads are consulted during the process of land-use planning and the approved plan for the commune is made available at the commune office. Our findings also indicate that engagement of villagers in communes and villages is very limited. Interviews with local people in $\mathrm{Na}$ Nhan Commune, for example, revealed that $57 \%$ of the interviewees claimed that they were not provided with any information on land-use planning and $18 \%$ of these mentioned that there was no impact of the land-use planning on their land use. About 35\% of the interviewees noted that they were not engaged in the process of land-use planning.

Insufficient information supporting land-use planning and preparation of land-use plans. Legal documents require baseline information to support preparation of land-use planning. However, our findings show that there is no spatial analysis of current land cover, assessment of land potential and suitability and market potential analyses nor a needs assessment for environmental services. Most information used for land-use planning is based on statistics and this follows a bottom-up reporting approach. Other information related to climate change, land potential assessment, markets etc is taken from literature reviews, if available. However, the studies on those matters are not available because they are not planned as part of the land-use planning process. Modelling and other planning tools are not used in the planning process at local levels. Inappropriate information used in land-use planning could lead to low quality and feasibility of the land-use planning and land-use plans.

Integration of sectoral planning into land-use planning is not effective. To date, there is no separate spatial sectoral planning for agriculture and forestry. These are developed in the form of national strategies (for example, the Viet Nam Forest Protection and Development Strategy 2006-2020, national strategy on agriculture and rural development 2011-2020 etc). These strategies provide national direction for sectoral development that are not suitable to integrate into provincial and district land-use planning. The newly approved Planning Law (VNA 2017) regulates the implementation of sectoral planning that includes national planning for forestry, environmental protection and biodiversity conservation. This planning will help better provide information for land-use planning across levels.

Unclear concept of integrated land-use planning and integration of green-growth development into planning processes: Existing legal documents do not clearly provide the concept of integrated land-use planning across levels. Consideration of environmental-related issues - such as environmental services, conservation areas - is not adequately addressed in 
the planning process. Though national green-growth development policies are available, detailed guidelines on implementation, particularly, lower-level planning (commune level) are lacking.

Lack of capacity for implementing land-use planning and land-use plans. The Department of Natural Resources and Environment at provincial and district levels (DONRE) is responsible for preparation of land-use planning and land-use plans. Their responsibility is for administration and management procedures and they are not directly involved in development of land-use planning and land-use plans. Consultancy firms are contracted to implement land-use planning and preparation of land-use plans. DONRE at provincial and district levels has responsibility for organization of reviews and approvals. District and provincial DONRE offices reported that implementation of land-use planning requires different expertise than that required to conducting the baseline survey. They agreed that the capacity of staff is limited, particularly, in the application of tools and software for spatial analysis and data management and analysis (for example, GIS and interpretation of remote-sensing imagery). In addition, staff capacity to assess ecosystem services for integration into planning is limited.

Limited investment for preparation of land-use planning. It was reported that the costs allocated to implement land-use planning and formulation of land-use plans are limited. In Dien Bien, the allocated fund for implementation of land-use planning is about VND 1 billion at district level and VND 2 billion at provincial level. This budget is intended to cover all costs of mapping, data analysis, reporting, consultation, appraisal and approval processes. Findings from discussions with district and provincial DONRE staff show that this fund is insufficient to conduct the key baseline assessment, such as land-suitability assessment, market survey, climate-change impacts, ecosystem services, to provide adequate information for planning, especially, for aspects of green-growth development. 


\section{Proposed institutional arrangements and monitoring framework for integrated tree-based landscape management}

\subsection{Approach and objectives}

The purpose of monitoring integrated tree-based landscape management is to understand how management of tree-based land uses can contribute to the green-growth strategy. The specific objectives of the monitoring follow.

- Provide evidence that each tree-based activity at landscape level has achieved its stated targets and impact over the planned time period and long-term perspective.

- Monitor the progress of implementing tree-based actions to ensure that they are on track with delivery of planned outputs and outcomes.

- Provide recommendations on efficient allocation of resources and improvement of institutional arrangements for managing natural resources to meet green-growth objectives.

The monitoring framework for integrated tree-based landscape management could be simple or sophisticated, depending on the financial and technical capacity of responsible actors. The simple approach for monitoring includes the following key steps.

- Formulating questions to ensure accurate assessment of the planned performance results and impacts.

- Developing indicators for monitoring that help reflect the questions asked.

- Developing a baseline that will be used as the benchmark to assess whether or not the planned outputs have been met.

- Gathering data and information thorough monitoring implementation.

- Overall assessment of outputs and impacts against the baseline for improvement and policy recommendations.

The monitoring framework should engage local participation across levels and external evaluation considering the capacity of stakeholders. It should also apply both qualitative and quantitative methods during data collection and assessment. The monitoring framework should be open for effective dialogue and feedback to continually refine the framework and improve landscape management to achieve the desired outcomes. The monitoring framework will help documentation of good practices and lessons learned for policy recommendations and longterm sustainable landscape management (see Annex 1 for additional information on designing a monitoring framework).

\subsection{Monitoring criteria and indicators}

The proposed criteria and indicators for monitoring focus on assessing 1) institutional arrangements for implementation of integrated tree-based planning; and 2) outcomes and impacts of integrated tree-based landscape management at commune level. 


\subsubsection{Monitoring institutional arrangements for implementation of integrated tree-based landscape planning}

This focusses on several key aspects of institutional arrangements for implementation of planning with regards to green-growth development, including 1) Availability of guiding documents for implementation of tree-based landscape planning; 2) Capacity building for stakeholders; 3) Implementation and decision-making process. (For details see Annex 2.)

$\circ$ Availability of guiding documents

This focuses on assessing the readiness of the legal framework for implementation of integrated tree-based landscape planning and includes the following.

1) Number of guiding documents provided

2) Relevance of the guiding documents

3) Level of detail of the guiding documents

4) Application of the guiding documents

- Capacity building for stakeholders

This assesses how capacity building is provided to the responsible management agencies and other stakeholders to support integrated tree-based landscape planning and management at commune level. The indicators include the following.

1) Number of training sessions organized (topic, participants etc)

2) Training material provided

3) Funding sources for training

4) Other meetings

- Implementation and decision-making process

This provides understanding of actual implementation and the decision-making process regarding the preparation and approval of integrated tree-based landscape plans and management. The proposed indicators include the following.

1) Required implementation of baseline assessment

2) Quality of tree-based landscape planning documents

3) Percentage of local people engaged in planning process

4) Number of consultation meetings

5) Satisfaction of local people with tree-based landscape plans

\subsubsection{Monitoring outcomes and impact of integrated tree-based landscape management}

The indicators for monitoring and assessing outcomes and impact include 1) State of physical natural capital; 2) Changes in ecosystem services; and 3) Impact on land-based socio-economics. The indicators should 1) reflect outcomes and impact; 2 ) measurable through quantitative and qualitative assessments; 3 ) Cost-effective. (For details see annexes 3 and 4.) 
- State of physical natural capital

These indicators aim to quantify how the physical capital (forests and land uses) change over time associated with landscape management plans compared to the baseline. The indicators are listed below.

1) Total forest area (ha)

2) Total natural forest area (ha)

3) Total plantation area (ha)

4) Protected forest area for headwater protection (ha)

5) Protected area for biodiversity conservation (ha)

6) Forest area for recreation and local culture (ha)

7) Restored forest area (ha)

8) Loss of forest area (ha)

9) Upland crop area without agroforestry practices (ha)

10) Upland crop area with agroforestry practices (ha)

11) Lowland annual crops (ha)

12) Improved home-garden area (ha)

- Changes in ecosystem services

The indicators are used to quantitatively and qualitatively assess the quality of ecosystems influenced by the change in forest and land-management practices. The indicators include the following.

1) Emission reductions from avoided deforestation and forest degradation $\left(\mathrm{tCO}_{2} \mathrm{e}\right)$

2) Carbon enhancement resultant from forest restoration and reforestation $\left(\mathrm{tCO}_{2} \mathrm{e}\right)$

3) Carbon enhancement from application of tree-based practices (agroforestry)

4) Soil erosion exposure

5) Water flow in dry season

6) Flood control

7) Biodiversity losses and conservation

8) Cultural and spiritual values

- Impact on land-based socio-economics

The indicators are used to assess socio-economic impact associated with forest and land-based management practices. They include the following.

1) Income from forests products (timber, non-timber forest products (VND/ha)

2) Income from payment for environmental services (VND/ha) 
3) Income from tree-based crops (agroforestry) (VND/ha)

4) Income from home-gardens (VND/ha)

5) Job creation in forestry-based activities (numbers, percentage of women)

6) Job creation and tree-based land management (numbers, percentage of women)

\subsection{Institutional arrangements for monitoring implementation}

The overall institutional arrangements for implementing tree-based landscape management are suggested in Figure 2. At provincial level, DONRE is the lead organization for monitoring implementation. DARD is a key partner. The direct agencies of DARD at provincial level are the Forest Protection Department and Agriculture Extension Centre. At district level, key actors that should be engaged in monitoring are DiNRE, DARD, Forest Protection Stations.

Figure 2. Institutional arrangements for monitoring of tree-based landscape management

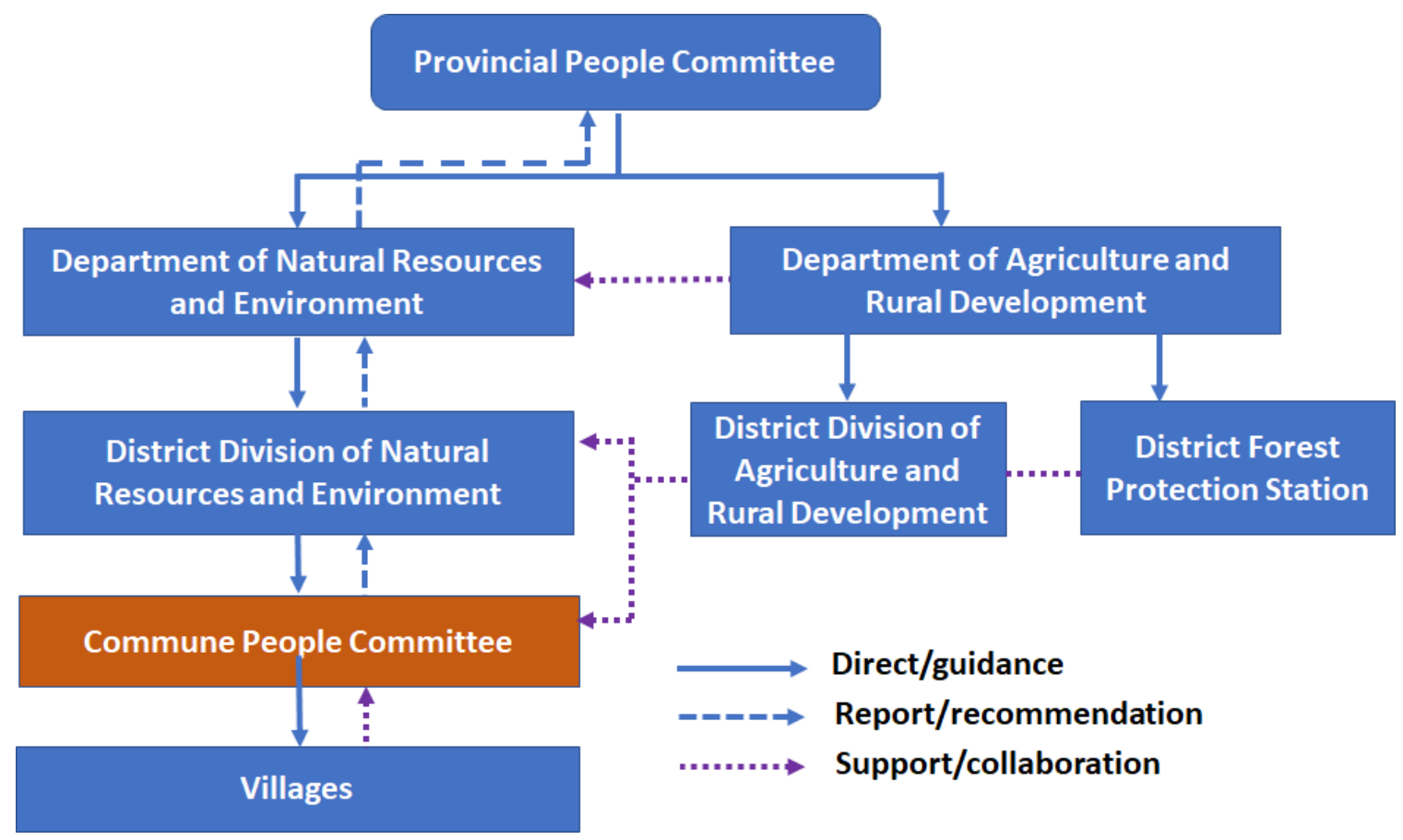

\subsubsection{Department of Natural Resources and Environment (DONRE)}

DONRE acts as the lead organization to coordinate implementation of monitoring communelevel tree-based landscape management. The key partner for supporting monitoring is DARD and its agencies at district level. A plan for a monitoring and collaboration mechanism should be agreed by both DONRE and DARD and then be approved by the Provincial People's Committee before monitoring is implemented. The responsibilities of DONRE are listed below. 
1) Prepare the monitoring plan

2) Prepare and mobilize resources for monitoring

3) Organize training on implementing monitoring

4) Coordinate and provide guidance for the implementation of monitoring

5) Make recommendations to provincial people's committees for improvement of treebased landscape management

\subsubsection{Department of Agriculture and Rural Development (DARD)}

DARD should work closely with DONRE under the approved collaboration mechanism to provide support to the implementation of monitoring, including the following.

1) Coordinate its line departments (such as Forest Protection, Forest Protection Station, district Division of Agricultural and Rural Development)

2) Provide support to data collection

3) Support capacity building

\subsubsection{District Division of Natural Resources and Environment (DiNRE)}

DiNRE should work under the guidance of DONRE and collaborate with line departments at district level to support implementation of the monitoring at commune level. The main responsibilities of DiNRE are listed below.

1) Support preparation of the monitoring plan

2) Support organization of training on implementation of monitoring

3) Coordinate and provide guidance for the implementation of monitoring at commune level

4) Support data collection and report preparation

5) Provide recommendations to DONRE for improvement

\subsubsection{Commune authorities}

Commune authorities are key actors in implementing monitoring. A commune should assign staff to be responsible for monitoring and reporting results. The tasks include the following.

1) Baseline information development: following criteria and indicators selected for monitoring integrated tree-based landscape management, baseline data need to be collected and compiled before monitoring starts. The baseline data for collection in specific areas of integrated tree-based landscape management are outlined in Annex 2.

2) Lead in data collection and compilation

3) Reporting monitoring results (see Annex 3) 


\subsubsection{Village heads}

Village heads in a commune will be required to work closely with responsible staff assigned by the commune authority to implement monitoring activities. The main tasks of the village heads follow.

1) Assisting in collecting baseline data

2) Assisting in collecting data used for monitoring (see annexes 2 and 4)

\subsubsection{Other line agencies}

This includes line agencies - such as Forest Protection, Agriculture Extension Centre - and projects and programs. These bodies should work closely with DONRE and DiNRE to provide support to the commune authority to implement monitoring, as listed below.

1) Capacity building for responsible staff of the commune and village heads regarding the implementation of monitoring, data analysis and reporting

2) Implement baseline assessment

3) Data collection for baseline information and monitoring

4) Provide expert support for estimation of emissions and carbon enhancement associated with tree-based land use management 


\section{References}

Amler B, Betke D, Eger H, Ehrich C, Kohler A, Kutter A, von Lossau A, Müller U, Seidemann S, Steurer R, Zimmermann W. 1999. Land use planning: methods, strategies and tools. Eschborn, Germany: Deutsche Gesellschaft für Technische Zusammenarbeit (GTZ) GmbH.

Bourgoin J, Castella J-C. 2011. 'PLUP FICTION': Landscape simulation for participatory land use planning in Northern Lao PDR. Mountain Research and Development 31:78-88. https://doi.org/10.1659/mrd- journal-d10-00129.1.

Bourgoin J, Castella J-C, Hett C, Lestrelin G, Heinimann A. 2013. Engaging local communities in low emissions land-use planning: a case study from Laos. Ecology and Society 18:9:1-9:11. https://doi.org/10.5751/ES05362-180209.

Bourgoin J, Castella J-C, Pullar D, Lestrelin G, Bouahom B. 2012. Toward a land zoning negotiation support platform: 'tips and tricks' for participatory land use planning in Laos. Landscape and Urban Planning 104:270-278. https://doi.org/10.1016/j.landurbplan.2011.11.008.

Cathcart J, Kline J, Delaney M, Tilton M. 2007. Carbon storage and Oregon's land-use planning program. Journal of Forestry 105:167-172.

Cockburn J, Cundill G, Shackleton S, Rouget M. 2018. Towards place-based research to support social-ecological stewardship. Sustainability 10:1434. https://doi.org/10.3390/su10051434

Do TH, Vu TP, Catacutan DC, Nguyen VT. 2019. Governing landscapes for ecosystem services: a participatory land-use scenario development in the Northwest Montane Region of Viet Nam. Ha Noi, Viet Nam: World Agroforestry (ICRAF).

Ducourtieux O, Laffort J-R, Sacklokham S. 2005. Land Policy and Farming Practices in Laos. Development and Change 36:499-526. https://doi.org/10.1111/j.0012-155X.2005.00421.x.

[FAO] Food and Agriculture Organization of the United Nations. 2016. The agriculture sectors in the Intended Nationally Determined Contributions: analysis. Authors: Strohmaier R, Rioux J, Seggel A, Meybeck A, Bernoux M, Salvatore M, Miranda J, Agostini A. Environment and Natural Resources Management Working Paper. FAO, Rome, Italy: Food and Agriculture Organization of the United Nations.

Hsu A, Brandt J, Widerberg O, Chan S, Weinfurter A. 2019. Exploring links between national climate strategies and non-state and subnational climate action in nationally determined contributions (NDCs). Climate Policy 1-15. https://doi.org/10.1080/14693062.2019.1624252.

Kauzeni AS, Kikula IS, Mohamed SA, Lyimo JG, Dabal-Clayton DB. 1993. Land use planning and resource assessment in Tanzania: a case study. London, UK: Environmental Planning Group, International Institute for Environment and Development.

Nelson E, Mendoza G, Regetz J, Polasky S, Tallis H, Cameron D, Chan KM, Daily GC, Goldstein J, Kareiva PM, Lonsdorf E, Naidoo R, Ricketts TH, Shaw M. 2009. Modeling multiple ecosystem services, biodiversity conservation, commodity production, and tradeoffs at landscape scales. Frontiers in Ecology and the Environment 7: 4-11. https://doi.org/10.1890/080023.

O'Farrell PJ, Anderson PML. 2010. Sustainable multifunctional landscapes: a review to implementation. Current Opinion in Environmental Sustainability 2:59-65. https://doi.org/10.1016/j.cosust.2010.02.005.

Reyers B, O'Farrell PJ, Nel JL, Wilson K. 2012. Expanding the conservation toolbox: conservation planning of multifunctional landscapes. Landscape Ecology 27:1121-1134. https://doi.org/10.1007/s10980-012-9761-0.

Rydin Y. 1998. Land use planning and environmental capacity: reassessing the use of regulatory policy tools to achieve sustainable development. Journal of Environmental Planning and Management 41:749-765. https://doi.org/10.1080/09640569811407.

[UNDP] United Nations Development Programme. 2018. Long-term greenhouse gas emission mitigation opportunities and drivers in Viet Nam: meeting Paris Agreement targets and accelerating progress towards the SDGs. Ha Noi, Viet Nam: United Nations Development Programme.

Vu TP, Do TH, Nguyen VT, Diep XT, Do AT. 2018. Improving land use planning: an integrated tree based planning approach: a policy brief for policy makers. Ha Noi, Viet Nam: World Agroforestry Centre (ICRAF). 


\section{Legal documents cited}

Prime Minister. 2021. Decision No. 523/QD-TTg dated 1 April 2021 of the Prime Minister approving the national forestry development strategy for a period of 2021-2030 and vision to 2050.

Prime Minister. 2012. Decision No. 1393/QD-TTg dated 25 September 2012 of the Prime Minister approving the national strategy on green growth.

Prime Minister. 2011. Decision No. 2139/QD-TTg dated 5 December 2011 of the Prime Minister approving the national strategy on climate change.

[VNA] Vietnam National Assembly. 2020. Environment Protection Law No. 72/2020/QH14 passed on 17 November 2020.

[VNA] Vietnam National Assembly. 2017. Forestry Law No. 16/2017/QH14 was passed on 15 November 2017 by the XIV National Assembly of the Socialist Republic of Vietnam.

[VNA] Vietnam National Assembly. 2017. Planning Law No. 21/2017/QH14 was passed on 24 November 2017 by the XIV National Assembly of the Socialist Republic of Vietnam.

[VNA] Vietnam National Assembly. 2013. Land Law No. 45/2013/QH13 was passed on 29 November 2013 by the XIII National Assembly of the Socialist Republic of Vietnam. 


\section{Annex 1. Additional guidelines on development of indicators for monitoring integrated tree-based landscape management}

\begin{tabular}{|c|c|}
\hline Key issues for consideration & Description \\
\hline $\begin{array}{l}\text { 1. Establish clear objectives for } \\
\text { the monitoring }\end{array}$ & $\begin{array}{l}\text { It is important to set goals under each aspect (natural capital, } \\
\text { ecosystem service or societal) to measure success against, even } \\
\text { if the ultimate land restoration goals are broad and to a degree, } \\
\text { 'open-ended'. Indicators should measure progress but do not } \\
\text { need to be explicitly linked to targets. }\end{array}$ \\
\hline $\begin{array}{l}\text { 2. Adopt metrics that } \\
\text { monitor outcomes not } \\
\text { activities }\end{array}$ & $\begin{array}{l}\text { Metrics should, wherever possible, include responses (physical } \\
\text { capital, such as area of forests, tree-based land uses etc, } \\
\text { selected ecosystem services, land-based socio-economic } \\
\text { impacts) and not just implementation itself. These principles } \\
\text { underpin monitoring requirements of integrated tree-based } \\
\text { landscape management. }\end{array}$ \\
\hline $\begin{array}{l}\text { 3. Identify interim objectives } \\
\text { (milestones) }\end{array}$ & $\begin{array}{l}\text { Given the complexities of working at large spatial scales and } \\
\text { over lengthy time-scales, consideration should be given to } \\
\text { identifying realistic interim outcomes. These should reflect } \\
\text { tangible and intended outputs (goods, services) or responses to } \\
\text { forest and land management activities that contribute, possibly } \\
\text { indirectly, to long-term, fundamental and durable change. }\end{array}$ \\
\hline $\begin{array}{l}\text { 4. Indicators should be } \\
\text { diagnostic, including contrasts, } \\
\text { controls or benchmarks, } \\
\text { where possible }\end{array}$ & $\begin{array}{l}\text { Indicators should show a strong relationship with the desired } \\
\text { outcome and, where relevant, incorporate controls, contrasts or } \\
\text { benchmarks to compare against changes in attributes of the } \\
\text { tree- based areas in a way that illustrates the effect of the } \\
\text { interventions. Some anticipated responses may not occur for } \\
\text { reasons that are outside of the implementer's control, even if } \\
\text { the program is successful. Some changes may occur owing to } \\
\text { factors unconnected to the program. To identify such instances, } \\
\text { methods for selected indicators (most likely those associated } \\
\text { with the program's outcomes; this won't be possible or } \\
\text { affordable for all indicators) should, ideally, include replication, } \\
\text { 'before and after comparisons', 'with and without intervention' } \\
\text { or other contrasts that help demonstrate a reliable, constant } \\
\text { and general response. This may require the collection of data } \\
\text { outside the area, where integrated tree-based landscape } \\
\text { management is not applied. }\end{array}$ \\
\hline $\begin{array}{l}\text { 5. Indicators should be cost } \\
\text { effective and easy to } \\
\text { understand }\end{array}$ & $\begin{array}{l}\text { Indicators based on summarized metrics from more complex } \\
\text { data (collected in the field, from remotely-sensed datasets or } \\
\text { obtained through interviews) provide a cost-effective means of } \\
\text { describing complex processes in simple terms. This helps provide } \\
\text { feedback and wider communication and facilitates pragmatic } \\
\text { data collection. }\end{array}$ \\
\hline
\end{tabular}




\begin{tabular}{|c|c|}
\hline Key issues for consideration & Description/explanation \\
\hline $\begin{array}{l}6 . \text { Indicators should be } \\
\text { robust, representative and } \\
\text { replicable }\end{array}$ & $\begin{array}{l}\text { To ensure interpretability and long-term comparability, } \\
\text { wherever possible, measures used as indicators should quantify } \\
\text { information in a way that is objective, representative (with an } \\
\text { appropriate sampling strategy), structured (to account for } \\
\text { temporal and spatial scales of information required), and } \\
\text { systematic (through careful design and a methodical approach) } \\
\text { to provide replicated information to monitor change through } \\
\text { time. Methods should ideally be well documented and well } \\
\text { established but the use of innovative methods is encouraged } \\
\text { where appropriate. }\end{array}$ \\
\hline $\begin{array}{l}\text { 7. A combination of } \\
\text { quantitative data together with } \\
\text { expert assessments are likely to } \\
\text { be required }\end{array}$ & $\begin{array}{l}\text { Where appropriate, data collected and indicators used should be } \\
\text { based on robust, quantitative assessments as described above so } \\
\text { they are transparent and repeatable. However, some measures } \\
\text { (for example, changes in institutional arrangements, legislation } \\
\text { or cultural practices) may be best captured using well- } \\
\text { established qualitative methods, narratives or expert } \\
\text { assessments in attributing changes. }\end{array}$ \\
\hline $\begin{array}{l}\text { 8. Use common frameworks } \\
\text { and existing data gathering, } \\
\text { where available }\end{array}$ & $\begin{array}{l}\text { The integrated tree-based landscape management guidance is } \\
\text { designed to ensure that monitoring is underpinned by a common } \\
\text { framework so that best use can be made of the information. } \\
\text { Where appropriate, this may include the use of common and } \\
\text { integrated protocols for data capture (for example, web-based } \\
\text { tools). Existing monitoring and data gathering - for example, } \\
\text { from national monitoring schemes, land-cover-change measures } \\
\text { or from population censuses - may provide important } \\
\text { information for impacts within and outside implementation } \\
\text { areas. }\end{array}$ \\
\hline $\begin{array}{l}\text { 9. Use methods that } \\
\text { are sustainable }\end{array}$ & $\begin{array}{l}\text { Monitoring methods need to be sustainable in terms of available } \\
\text { resources and commitment to collect information in a consistent } \\
\text { and repeatable manner. Measures should cover expected short- } \\
\text { term responses as well as proxies or longer-term indicators likely } \\
\text { to be sustainable through capacity building. Programs should } \\
\text { demonstrate how they will sustain long-term monitoring. }\end{array}$ \\
\hline
\end{tabular}


Annex 2. Baseline information collection

\section{A. Institutional arrangement baseline (for year .....)}

\begin{tabular}{|c|c|c|}
\hline ID & $\begin{array}{l}\text { Criteria } \\
\text { Indicator }\end{array}$ & Data/rating \\
\hline I & Availability of guiding documents & \\
\hline 1 & Numbers of guiding documents (policies, guidelines etc) & \\
\hline 2 & Relevance of guiding documents (high, medium, low) & \\
\hline 3 & $\begin{array}{l}\text { Level of detail of the guiding documents (comprehensive, sufficient, } \\
\text { not sufficient) }\end{array}$ & \\
\hline 4 & Application of the guiding documents & \\
\hline II & Staff capacity & \\
\hline 1 & $\begin{array}{l}\text { Number of responsible staff in responsible agencies across levels } \\
\text { (commune, district and province) }\end{array}$ & \\
\hline 2 & $\begin{array}{l}\text { Number of staff by expertise in responsible agencies across levels } \\
\text { (commune, district and province) }\end{array}$ & \\
\hline 3 & $\begin{array}{l}\text { Number of training sessions organized annually across levels } \\
\text { (commune, district and province) }\end{array}$ & \\
\hline 4 & $\begin{array}{l}\text { Annual funding provided for building staff capacity across levels } \\
\text { (commune, district and province) }\end{array}$ & \\
\hline III & Implementation and decision-making process & \\
\hline 1 & Baseline assessment for land-use planning & \\
\hline 2 & $\begin{array}{l}\text { Quality of tree-based landscape planning document (good, medium, } \\
\text { poor) }\end{array}$ & \\
\hline 3 & Engagement of local people in planning (yes/no) & \\
\hline 4 & Number of consultation meetings & \\
\hline 5 & Satisfaction of local people with tree-based landscape plans & \\
\hline
\end{tabular}

B. Tree-based landscape baseline (for year .........)

\begin{tabular}{|l|l|l|}
\hline ID & $\begin{array}{l}\text { Criteria } \\
\text { Indicators }\end{array}$ & Data/rating \\
\hline I & Physical capital & \\
\hline 1 & Total forest area (ha) & \\
\hline 2 & Total natural forest area (ha) & \\
\hline 3 & Total plantation area (ha) & \\
\hline 4 & Protected forest area for headwater protection (ha) & \\
\hline
\end{tabular}




\begin{tabular}{|c|c|}
\hline 5 & Protected area for biodiversity conservation (ha) \\
\hline 6 & Forest area for recreation and local culture (ha) \\
\hline 7 & Forest area managed by community (ha) \\
\hline 8 & Forest area managed by State organizations (ha) \\
\hline 9 & Forest area managed by smallholders (ha) \\
\hline 10 & Upland crop area without agroforestry practices (ha) \\
\hline 11 & Upland crop area with agroforestry practices (ha) \\
\hline 12 & Lowland annual crops (ha) \\
\hline 13 & Home-garden area (ha) \\
\hline II & Ecosystem services \\
\hline 1 & Carbon stocks of forests and land uses \\
\hline 2 & Soil erosion in upland area (high/moderate/low) \\
\hline 3 & Water flows in dry season (high/moderate/low) \\
\hline 4 & Flood frequency (frequent/moderate/few) \\
\hline 5 & Biodiversity values (high/medium/low) \\
\hline 6 & Cultural and spiritual values (high/medium/low) \\
\hline III & Land-based socio-economics \\
\hline 1 & Income from forest products (timber, NTFPs) (VND/ha) \\
\hline 2 & Income from payment for environmental services (VND/ha) \\
\hline 3 & Income from tree-based crops (agroforestry) (VND/ha) \\
\hline 4 & Income from upland crops (without trees) (VND/ha) \\
\hline 5 & Income from home-gardens (VND/ha) \\
\hline 6 & $\begin{array}{l}\text { Number of persons engaged in forestry-based activities } \\
\text { and percentage of women (\%) }\end{array}$ \\
\hline 7 & $\begin{array}{l}\text { Number of persons engaged in tree-based land management } \\
\text { and percentage of women (\%) }\end{array}$ \\
\hline
\end{tabular}


Annex 3. Monitoring framework for integrated tree-based landscape management

\section{A. Institutional arrangements}

\begin{tabular}{|c|c|c|c|c|c|}
\hline ID & Indicator & Method & Frequency & $\begin{array}{l}\text { Responsible } \\
\text { actor }\end{array}$ & Expected output \\
\hline $\mathbf{I}$ & Availability of guiding documents & & & & \\
\hline 1 & $\begin{array}{l}\text { Number of guiding documents (policies, guidelines } \\
\text { etc) }\end{array}$ & $\begin{array}{l}\text { Review and } \\
\text { interview }\end{array}$ & Annually & DONRE & $\begin{array}{l}\text { List of guiding } \\
\text { documents }\end{array}$ \\
\hline 2 & $\begin{array}{l}\text { Relevance of guiding documents (high, medium, } \\
\text { low) }\end{array}$ & $\begin{array}{l}\text { Review and } \\
\text { interview }\end{array}$ & Annually & DONRE & Assessment \\
\hline 4 & $\begin{array}{l}\text { Application of the guiding documents (not at } \\
\text { all, partially and widely) }\end{array}$ & $\begin{array}{l}\text { Review and } \\
\text { interview }\end{array}$ & Annually & DONRE & Assessment \\
\hline II & Staff capacity & & & & \\
\hline 1 & $\begin{array}{l}\text { Number of responsible staff in management agencies } \\
\text { across levels (commune, district and province) }\end{array}$ & $\begin{array}{l}\text { Review and } \\
\text { interview }\end{array}$ & Annually & DONRE & Data \\
\hline 3 & $\begin{array}{l}\text { Number of training sessions organized annually } \\
\text { across levels (commune, district, province) }\end{array}$ & $\begin{array}{l}\text { Review and } \\
\text { interview }\end{array}$ & Annually & DONRE & Data \\
\hline 4 & $\begin{array}{l}\text { Annual funding provided for building staff capacity } \\
\text { across levels (commune, district, province) }\end{array}$ & $\begin{array}{l}\text { Review and } \\
\text { interview }\end{array}$ & Annually & DONRE & Data \\
\hline III & Implementation and decision-making process & & & & \\
\hline 1 & Baseline assessment for land-use planning & $\begin{array}{l}\text { Review and } \\
\text { interview }\end{array}$ & Annually & DONRE & Assessment \\
\hline 2 & $\begin{array}{l}\text { Quality of tree-based landscape planning document } \\
\text { (good, medium, poor) }\end{array}$ & Review and & Annually & DONRE & Assessment \\
\hline
\end{tabular}




\begin{tabular}{|l|l|l|l|l|l|}
\hline & & interview & & \\
\hline 3 & Percentage of local people involved in planning & $\begin{array}{l}\text { Review and } \\
\text { interview }\end{array}$ & Annually & DONRE & Data \\
\hline 4 & Number of consultation meetings & $\begin{array}{l}\text { Review and } \\
\text { interview }\end{array}$ & Annually & DONRE & Data \\
\hline 5 & $\begin{array}{l}\text { Satisfaction of local people with tree-based } \\
\text { landscape plans }\end{array}$ & $\begin{array}{l}\text { Review and } \\
\text { interview }\end{array}$ & Annually & DONRE & Assessment \\
\hline
\end{tabular}




\section{B. Change in physical natural capital (compared to baseline data)}

\begin{tabular}{|c|c|c|c|c|}
\hline Indicator & Method & Frequency & Responsible actor & Expected output \\
\hline 1. Total forest area (ha) & $\begin{array}{l}\text { Statistical data collection; } \\
\text { spatial assessment }\end{array}$ & Annually & Commune authority & Area change data \\
\hline 2. Total natural forest area (ha) & $\begin{array}{l}\text { Statistical data collection; } \\
\text { spatial assessment }\end{array}$ & Annually & Commune authority & Area change data \\
\hline 3. Total plantation area (ha) & $\begin{array}{l}\text { Statistical data collection; } \\
\text { spatial assessment }\end{array}$ & Annually & Commune authority & Area change data \\
\hline $\begin{array}{l}\text { 4. Protected forest area for } \\
\text { headwater protection (ha) }\end{array}$ & $\begin{array}{l}\text { Statistical data collection; } \\
\text { spatial assessment }\end{array}$ & Annually & Commune authority & Area change data \\
\hline $\begin{array}{l}\text { 5. Protected area for } \\
\text { biodiversity conservation (ha) }\end{array}$ & $\begin{array}{l}\text { Statistical data collection; } \\
\text { spatial assessment }\end{array}$ & Annually & Commune authority & Area change data \\
\hline $\begin{array}{l}\text { 6. Forest area for recreation and } \\
\text { local culture (ha) }\end{array}$ & $\begin{array}{l}\text { Statistical data collection; } \\
\text { spatial assessment }\end{array}$ & Annually & Commune authority & Area change data \\
\hline 7. Restored forest area (ha) & $\begin{array}{l}\text { Statistical data collection; } \\
\text { spatial assessment }\end{array}$ & Annually & Commune authority & Area change data \\
\hline 8. Loss of forest area (ha) & $\begin{array}{l}\text { Statistical data collection; } \\
\text { spatial assessment }\end{array}$ & Annually & Commune authority & Area change data \\
\hline $\begin{array}{l}\text { 9. Upland crop area without } \\
\text { agroforestry practices (ha) }\end{array}$ & $\begin{array}{l}\text { Statistical data collection; } \\
\text { spatial assessment }\end{array}$ & Annually & Commune authority & Area change data \\
\hline $\begin{array}{l}\text { 10. Upland crop area with } \\
\text { agroforestry practices (ha) }\end{array}$ & $\begin{array}{l}\text { Statistical data collection; } \\
\text { spatial assessment }\end{array}$ & Annually & Commune authority & Area change data \\
\hline 11. Lowland annual crops (ha) & $\begin{array}{l}\text { Statistical data collection; } \\
\text { spatial assessment }\end{array}$ & Annually & Commune authority & Area change data \\
\hline 12. Improved home-garden area (ha) & $\begin{array}{l}\text { Statistical data collection; } \\
\text { spatial assessment }\end{array}$ & Annually & Commune authority & Area change data \\
\hline
\end{tabular}




\section{Change in ecosystem services}

\begin{tabular}{|c|c|c|c|c|}
\hline Indicators & Monitoring methods & Frequency & Responsible actors & Expected outputs \\
\hline $\begin{array}{l}\text { 2. Carbon enhancement resultant } \\
\text { from forest restoration and } \\
\text { reforestation }\left(\mathrm{tCO}_{2} \mathrm{e}\right)\end{array}$ & $\begin{array}{l}\text { Stock-change method; } \\
\text { expert assessment }\end{array}$ & Annually & Expert assessment & $\begin{array}{l}\text { Carbon-change } \\
\text { estimates for } \\
\text { restoration and } \\
\text { reforestation }\end{array}$ \\
\hline $\begin{array}{l}\text { 3. Carbon enhancement from } \\
\text { application of tree-based practices } \\
\text { (agroforestry) }\left(\mathrm{tCO}_{2} \mathrm{e}\right)\end{array}$ & $\begin{array}{l}\text { Stock-change method; } \\
\text { expert assessment }\end{array}$ & Annually & Expert assessment & $\begin{array}{l}\text { Carbon-change } \\
\text { estimates for tree-based } \\
\text { land uses }\end{array}$ \\
\hline 4. Soil erosion & $\begin{array}{l}\text { Participatory assessment; } \\
\text { score-card method }\end{array}$ & Annually & Village heads & Qualitative assessment \\
\hline 7. Biodiversity loss & $\begin{array}{l}\text { Participatory assessment; } \\
\text { score-card method; statistical } \\
\text { data }\end{array}$ & Annually & Village heads & $\begin{array}{l}\text { Qualitative } \\
\text { assessment; statistical } \\
\text { data on endangered } \\
\text { species }\end{array}$ \\
\hline 8. Cultural and spiritual values & $\begin{array}{l}\text { Participatory assessment; } \\
\text { score-card method }\end{array}$ & Annually & Village heads & Qualitative assessment \\
\hline
\end{tabular}




\section{Change in ecosystem services}

\begin{tabular}{|l|l|l|l|l|}
\hline Indicators & Monitoring methods & Frequency & Responsible actors & Expected outputs \\
\hline $\begin{array}{l}\text { 1. Income from forest products (timber, } \\
\text { non-timber forest products) (VND/ha) }\end{array}$ & Statistical and sample survey & Annually & Commune authority & Income data \\
\hline $\begin{array}{l}\text { 2. Income from payment for } \\
\text { environmental services (VND/ha) }\end{array}$ & Statistical and sample survey & Annually & Commune authority & Income data \\
\hline $\begin{array}{l}\text { 3. Income from tree-based crops } \\
\text { (agroforestry) (VND/ha) }\end{array}$ & Statistical and sample survey & Annually & Commune authority & Income data \\
\hline $\begin{array}{l}\text { 4. Income from home-gardens (VND/ha) } \\
\text { 5. Job creation in forestry-based }\end{array}$ & Statistical and sample survey & Annually & Commune authority & Income data \\
\hline $\begin{array}{l}\text { 6. Job creation in tree-based } \\
\text { land management }\end{array}$ & Statistical and sample survey & Annually & Commune authority & $\begin{array}{l}\text { Number of jobs created } \\
\text { and percentage of } \\
\text { women involved (\%) }\end{array}$ \\
\hline
\end{tabular}




\section{Working paper series}

2017

252. Preferensi Petani terhadap Topik Penyuluhan dan Penyebaran Informasi Agroforestri di Indonesia http://dx.doi.org/10.5716/WP16181.PDF

253. Seri Agroforestri dan Kehutanan di Sulawesi: Keanekaragaman hayati jenis pohon pada hutan rakyat agroforestri di DAS Balangtieng, Sulawesi Selatan

http://dx.doi.org/10.5716/WP16182.PDF

254. Potensi dan Tantangan dalam Pengembangan Skema Ko-Investasi Jasa Lingkungan di

Kabupaten Buol, Indonesia. http://dx.doi.org/10.5716/WP17008.PDF

255. Keragaman Jenis Pohon dan Pemanfaatannya oleh Masyarakat di Kabupaten Buol, Indonesia. http://dx.doi.org/10.5716/WP17009.PDF

256. Kerentanan dan preferensi sistem pertanian petani di Kabupaten Buol, Indonesia

http://dx.doi.org/10.5716/WP17010.PDF

257. Dinamika Perubahan Penggunaan/Tutupan Lahan Serta Cadangan Karbon di Kabupaten

Buol, Indonesia. http://dx.doi.org/10.5716/WP17011.PDF

258. The effectiveness of the volunteer farmer trainer approach vis-à-vis other information sources in dissemination of livestock feed technologies in Uganda.

http://dx.doi.org/10.5716/WP17104.PDF

259. Agroforestry and forestry in Sulawesi series: Impact of agricultural-extension booklets on community livelihoods in South and Southeast Sulawesi.

http://dx.doi.org/10.5716/WP17125.PDF

260. Petani Menjadi Penyuluh, Mungkinkah? Sebuah Pendekatan Penyuluhan dari Petani ke Petani di Kabupaten Sumb Timur. http://dx.doi.org/10.5716/WP17145.PDF

261. Dampak Perubahan Tutupan Lahan terhadap Kondisi Hidrologi di Das Buol, Kabupaten

Buol, Sulawesi Tengah: Simulasi dengan Model Genriver

http://dx.doi.org/10.5716/WP17146.PDF

262. Analisis Tapak Mata Air Umbulan, Pasuruan, Jawa Timur. Kajian elemen biofisik dan

persepsi masyarakat. http://dx.doi.org/10.5716/WP17147.PDF

263. Planned comparisons demystified. http://dx.doi.org/10.5716/WP17354.PDF 264. Soil

health decision support for NERC digital soil platforms: A survey report.

http://dx.doi.org/10.5716/WP17355.PDF

265. Seri Pembangunan Ekonomi Pedesaan Indonesia: Menanam di bukit gundul:

Pengetahuan masyarakat lokal dalam upaya restorasi lahan di Sumba

Timur. http://dx.doi.org/10.5716/WP17356.PDF

266. Tree diversity and carbon stock in three districts of Kutai Timur, Pasir and Berau, East

Kalimantan http://dx.doi.org/10.5716/WP17357.PDF

267. Tree Diversity and Carbon Stock in Various Land Use Systems of Banyuasin and Musi

Banyuasin Districts, South Sumatera http://dx.doi.org/10.5716/WP17358.PDF

268. Tree diversity and carbon stock in various land cover systems of Jayapura, Jayawijaya

and Merauke Districts, Papua Province http://dx.doi.org/10.5716/WP17359.PDF

269. Modelling tree production based on farmers' knowledge: case for kapok (Ceiba

pentandra) and candlenut (Aleurites mollucana) under various agroforestry scenarios.

http://dx.doi.org/10.5716/WP17361.PDF

270. The Impact of Land Cover and Climate Change on Present and Future Watershed

Condition. Study case: Tugasan, Alanib and Kulasihan Sub-watershed of Manupali Watershed, Lantapan, Bukidnon, Philippines. http://dx.doi.org/10.5716/WP17362.PDF 
271. Tree Diversity and Above-ground Carbon Stock estimation in Various Land use Systems in Banjarnegara, Banyumas and Purbalingga, Central Java.

http://dx.doi.org/10.5716/WP17363.PDF

272. Agroforestry and Forestry in Sulawesi series: Landscape Management Strategies in

Sulawesi: Review of Intervention Options. http://dx.doi.org/10.5716/WP17364.PDF

273. Household Food-Security and Nutritional Status of Women and Children in Buol Regency, Central Sulawesi, Indonesia. http://dx.doi.org/10.5716/WP17365.PDF

274. Palm oil expansion in tropical forest margins or sustainability of production? Focal issues of regulations and private standards. http://dx.doi.org/10.5716/WP17366.PDF

\section{8}

275. Decision analysis methods guide: Agricultural policy for nutrition. http://dx.doi.org/10.5716/WP18001.PDF

276. Supporting human nutrition in Africa through the integration of new and orphan crops into food systems: Placing the work of the African Orphan Crops Consortium in context.

http://dx.doi.org/10.5716/WP18003.PDF

277. Seri Pembangunan Ekonomi Pedesaan Indonesia. Pilihan Manajemen Budidaya Kacang Tanah sebagai Upaya untuk Memperbaiki Penghidupan Masyarakat Haharu.

http://dx.doi.org/10.5716/WP18004.PDF

278. Estudio de línea de base CCAFS a nivel de hogar en Nicaragua y Costa Rica

Fase de diagnóstico del estudio: "Contribución de la diversidad arbórea a los medios de vida

para la adaptación y la mitigación al cambio climático http://dx.doi.org/10.5716/WP18005.PDF

279. Understanding tree cover transition, drivers and stakeholder perspectives for effective landscape governance. A case study in Na Nhan commune, Dien Bien province, Vietnam.

http://dx.doi.org/10.5716/WP18006.PDF

280. El Sistema "Quesungual": Agroforestería y manejo de suelos para la producción de maíz y frijol en laderas. http://dx.doi.org/10.5716/WP18007.PDF

281: Probabilistic Decision Modelling to Determine Impacts on Natural Resource Management and Livelihood Resilience in Marsabit County, Kenya. http://dx.doi.org/10.5716/WP18008.PDF

282. Shifting discourse, shifting power: how is climate change mitigation and justice negotiated in Indonesia? http://dx.doi.org/10.5716/WP18009.PDF

283. Result of Land Use Planning and Land Administration (LULA) Implementation in South

Sumatra, East Kalimantan, Central Java and Papua http://dx.doi.org/10.5716/WP18010.PDF

284. Farmers' preferences for training topics and dissemination of agroforestry information in Indonesia. http://dx.doi.org/10.5716/WP18015.PDF

285. CSA-Diagnostic (CSA-Dx): A primer for investigating the 'climate-smartness' of ag technologies http://dx.doi.org/10.5716/WP18020.PDF

286. An analysis of the vulnerability of poor communities in Yunnan Province, China http://dx.doi.org/10.5716/WP18021.PDF

287. Gendered space and quality of life: gender study of out-migration and smallholding agroforestry communities in West Java Province, Indonesia.

http://dx.doi.org/10.5716/WP18024.PDF

288: Evaluation of UTZ certification coffee businesses in Guatemala, Honduras and Nicaragua. http://dx.doi.org/10.5716/WP18028.PDF

289. Agroforestry species of Peru: annotated list and contribution to prioritization for genetic conservation. http://dx.doi.org/10.5716/WP18029.PDF

290. Indonesia Rural Economic Development Series.Growing plants on a barren hill: local knowledge as part of land restoration in Sumba Timur, Indonesia.

http://dx.doi.org/10.5716/WP18030.PDF

291. Assessing the Downstream Socioeconomic Impacts of Agroforestry in Kenya 
292: Los árboles fuera del bosque en la NAMA forestal de Colombia. Elementos conceptuales para su contabilización. http://dx.doi.org/10.5716/WP19002.PDF

293: Gender and Adaptation: An Analysis of Poverty and Vulnerability in Yunnan, China.

http://dx.doi.org/10.5716/WP19004.PDF

294: Tree Cover on Agricultural Land in the Asia Pacific Region.

http://dx.doi.org/10.5716/WP19005.PDF

295: What do we really know about the impacts of improved grain legumes and dryland cereals? A critical review of 18 impact studies.vhttp://dx.doi.org/10.5716/WP19006.PDF 296: Breeders' views on the production of new and orphan crops in Africa: a survey of constraints and opportunities. http://dx.doi.org/10.5716/WP19007.PDF

297: Biomass Resources in Rhino Camp and Imvepi Refugee Settlements and the Buffer Zone around these Settlements in West Nile, Uganda. http://dx.doi.org/10.5716/WP19031.PDF 298: Option for restocking woody biomass in refugee-hosting areas: Perspectives from communities in Rhino Camp and Imvepi Settlements, Uganda.

http://dx.doi.org/10.5716/WP19032.PDF

299: Restoring ecosystems in refugee settlements using tree-based systems: The case of Rhino Camp and Imvepi Settlements in Uganda.

http://dx.doi.org/10.5716/WP19033.PDF

300: A theory-based evaluation of the Agroforestry Food Security Programme, Phase II in Malawi (AFSPII): Lessons for Scaling Up Complex Agronomic and Natural Resource Management Practices Developed and Tested in Research Settings.

http://dx.doi.org/10.5716/WP19036.PDF

301: Fuentes semilleras y especies agroforestales de los bosques secos tropicales del norte del Perú: estado actual y prioridades futuras. (Spanish)

http://dx.doi.org/10.5716/WP19057.PDF

302: Seed sources and agroforestry species of tropical dry forests of northern Peru: current status and future priorities. (English)

http://dx.doi.org/10.5716/WP19058.PDF

303: Turmeric Production under Shade Management and Fertilization in Degraded Landscapes of Sumba Timur.

http://dx.doi.org/10.5716/WP19066.PDF

2020

304: From Tree Planting to Tree Growing: Rethinking Ecosystem Restoration Through Trees. http://dx.doi.org/10.5716/WP20001.PDF

305: Agroforestry species of Peru: Reference list and contribution to prioritization for the conservation of agroforestry genetic resources.

http://dx.doi.org/10.5716/WP20013.PDF

306: An exploratory analysis of cost-benefit analysis of landscape restoration.

http://dx.doi.org/10.5716/WP20014.PDF

307: Wood fuel value chains in Kenya: a 20-year synthesis.

http://dx.doi.org/10.5716/WP20026.PDF

308: Especies agroforestales del Perú: Lista referencial y contribución a la priorización para la conservación de recursos genéticos agroforestales. Documento de Trabajo número 308.

Centro Internacional de Investigación Agroforestal

http://dx.doi.org/10.5716/WP20041.PDF 
309: Simulasi Dampak Perubahan Tutupan Lahan dan Curah Hujan di DAS Citarum Hulu dengan Model GenRiver: Kalibrasi model dan analisa sensitivitas.

http://dx.doi.org/10.5716/WP20048.PDF

310: Simulating the effect of change in land cover and rainfall in Upper Citarum Watershed:

calibration and sensitivity analysis of Genriver model

http://dx.doi.org/10.5716/WP20049.PDF

311: Status of Perennial Tree Germplasm Resources in India and their Utilization in the Context

of Global Genome Sequencing Efforts. http://dx.doi.org/10.5716/WP2020050.PDF

2021

312: The one hundred tree species prioritized for planting in the tropics and subtropics as indicated by database mining. World Agroforestry, Nairobi, Kenya.

http://dx.doi.org/10.5716/WP21001.PDF

313: Amaruzaman S, Isnurdiansyah B L. 2021. Land-use Land-cover Change and Farming

systems in the upland of Pagar Alam City, Indonesia. http://dx.doi.org/10.5716/WP21007.PDF

314: Effect of COVID-19 on rural community enterprises: the case of community forest enterprises in Cameroon.

http://dx.doi.org/10.5716/WP21007.PDF

315: Assessment of women's benefits and constraints in participating in agroforestry exemplar landscapes. https://dx.doi.org/10.5716/WP21021.PDF

316: Adoption of improved grain legumes and dryland cereals crop varieties: A synthesis of evidence. https://dx.doi.org/10.5716/WP21022.PDF

317: Understanding tree-cover transitions, drivers and stakeholders' perspectives for effective landscape governance: a case study of Chieng Yen Commune, Son La Province, Viet Nam.

https://dx.doi.org/10.5716/WP21023.PDF 
World Agroforestry (ICRAF) is a centre of scientific and development excellence that harnesses the benefits of trees for people and the environment. Leveraging the world's largest repository of agroforestry science and information, we develop knowledge practices, from farmers' fields to the global sphere, to ensure food security and environmental sustainability.

ICRAF is the only institution that does globally significant agroforestry research in and for all of the developing tropics. Knowledge produced by ICRAF enables governments, development agencies and farmers to utilize the power of trees to make farming and livelihoods more environmentally, socially and economically sustainable at multiple scales.

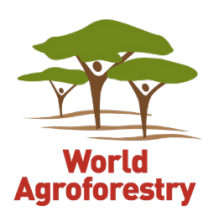

United Nations Avenue, Gigiri • PO Box 30677 • Nairobi, $00100 \cdot$ Kenya

Telephone: +254207224000 or via USA +1 6508336645

Fax: +254207224001 or via USA +1650 8336646

Email: worldagroforestry@cgiar.org •www.worldagroforestry.org 